\title{
Importance of Further Research on Leishmania Biology
}

\author{
Kaleab Tesfaye Tegegne $^{1 *}$, Abiyu Ayalew Assefa ${ }^{1}$, Mekibib Kassa Tessema ${ }^{2}$, Eleni Tesfaye \\ Tegegne $^{3}$, Alelign Tadele Abebe ${ }^{4}$, Belayneh Feleke Weldeyes ${ }^{5}$ and Wosenyeleh Semeon \\ Bagajjo $^{6}$ \\ ${ }^{1}$ Department of Public Health, Hawassa College of Health Science, Ethiopia
}

${ }^{2}$ Leishmania Research and Treatment Center, University of Gondar, Ethiopia

${ }^{3}$ College of Medicine and Health Science, University of Gondar, Ethiopia

${ }^{4}$ Department of Medical Laboratory Technology, Hawassa College of Health Science, Ethiopia

${ }^{5}$ Department of Midwifery, Hawassa College of Health Science, Ethiopia

${ }^{6}$ Dean of Hawassa College of Health Science, Ethiopia

*Corresponding author: Kaleab Tesfaye Tegegne, Department of Public Health, Hawassa College of Health Science, Ethiopia.

To Cite This Article: Kaleab Tesfaye T, Abiyu Ayalew A, Mekibib Kassa T, Eleni Tesfaye T, Alelign Tadele A, et al., Importance of Further Research on Leishmania Biology. Am J Biomed Sci \& Res. 2021 - 12(5). AJBSR.MS.ID.001787. DOI: 10.34297/AJBSR.2021.12.001787.

Received: 監 April 28, 2021; Published: 眥 April 29, 2021

\section{Opinion}

Diagnosis of Leishmania infection is insensitive and nonspecific. Knowledge of Leishmania biochemistry and genetics is very essential. The Leishmania genome size is nearly $34 \mathrm{Mb}$ and chromosomes size range from 0.3 to $2.8 \mathrm{Mb}[1,2]$. The Leishmania karyotype is conserved from species of Leishmania and the genes are syntenic [1-4]. The sequence of the smallest Leishmania chromosome was completed in 1998 and 79 protein-coding genes were identified [5]. Recently, one thousand complete genes have been identified from the cosmid sequencing [6] New molecular tools like regulatable promoter system for analysis of Leishmania biology, will increase our knowledge and help in the prevention and control of Leishmania disease [6]. There is no vaccine that is effective for human leishmaniasis because factors that are involved in the development of specific memory cells for Leishmania and long-lasting immunity are not fully understood until now [7]. Recently, it is unknown how memory cells are developed, persisted and eliminated after Leishmania infection. Long-lasting immunity occurs when there is persistence of live parasites around the areas of infection [8]. Currently, we are able to develop long-lasting immunity when there are no live and reproducing parasites [9]. Vaccine development has two aspects; the first is formulation and second is delivery.
Previous studies indicated that encapsulation of antigens in nanoparticles, liposomes or addition of adjuvants increasingly improves their immunogenicity and ability to prevent [10-12] and this calls the need for further studies to improve vaccine delivery. In future, leishmaniasis could be a global public health problem that can affect people in developed countries. The introduction of a vaccine will prevent an estimated 350 million people who are at risk of Leishmania disease from Leishmania disease in the world [13] Further studies should be done to identify the mechanisms for persistence of memory cells of Leishmania developed in vivo by booster doses of vaccine made from killed Leishmania parasites. We would like to recommend investors and pharmaceutical industries to do interventional studies for vaccine development. Anthropological research that focuses on gender will be useful to analyze how the effect of communicable diseases vary among men and women and may be used in planning gender-based prevention, strategies.

\section{References}

1. Wincker P, Ravel C, Blaineau C, Pages M, Jauffret Y, et al. (1996) Nucleic Acids Res 24:1688-1694.

2. Bastien P, Blaineau C, Britto C, Dedet JP, Dubessay P, et al. (1998) Parasitol. Today 14: 301-303 
3. Britto C, Ravel C, Bastien P, Blaineau C, Page's M, et al. (1998) Gene 222: 107-117

4. Ravel C, Dubessay P, Britto C, Blaineau C, Bastien P et al. (1999) Nucleic Acids Res. 27: 2473-2477

5. Myler PJ, Audleman L, deVos T, Hixson G, Kiser P, et al. (1999) Proc Natl Acad Sci USA 96: 2902-2906

6. Myler PJ (2000) Gene Action and Cellular Function in Parasitic protozoa Biochemical Society Transactions 28(5).

7. Zaph C, Uzonna J, Beverley SM, Scott P (2004) Central memory T cells mediate long-term immunity to Leishmania major in the absence of persistent parasites. Nat Med 10(10): 1104-1110.

8. Uzonna JE, Wei G, Yurkowski D, Bretscher P (2001) Immune elimination of Leishmania major in mice: implications for immune memory, vaccination, and reactivation disease. J Immunol 167(12): 6967-6974.
9. Okwor I, Kuriakose S, Uzonna J (2010) Repeated inoculation of killed Leishmania major induces durable immune response that protects mice against virulent challenge. Vaccine 28(33): 5451-5457.

10. Bhowmick S, Mazumdar T, Sinha R, Ali N (2010) Comparison of liposome based antigen delivery systems for protection against Leishmania donovani. J Control Release 141(2): 199-207.

11. Doroud D, Zahedifard F, Vatanara A, Najafabadi AR, Taslimi Y, et al. (2011) Delivery of a cocktail DNA vaccine encoding cysteine proteinases type I, II and III with solid lipid nanoparticles potentiate protective immunity against Leishmania major infection. J Control Release 153(2): 154-162.

12. Doroud D, Zahedifard F, Vatanara A, Najafabadi AR, Rafati S (2011) Cysteine proteinase type I, encapsulated in solid lipid nanoparticles induces substantial protection against Leishmania major infection in C57BL/6 mice. Parasite Immunol 33(6): 335-348.

13. Okwor and Uzonna (2016) Social and Economic Burden of Human Leishmaniasis. Am J Trop Medd Hyg 94(3): 489-493. 